\title{
Management by Values - a strategic dimension
}

Prof. Kazimierz Krzakiewicz University of Economics in Poznań Faculty of Management

\section{Introduction}

An organization, seen as a complex and dynamic system, is closely correlated with the environment. Therefore, it is necessary to look for new principles of its operation, based on values, which determine the organizational behaviour.

Initially, the approach to management, which focused on the creation of a new value for the company owners (shareholders), being the company's main objective, was exclusively economic. It was defined as ValueBased Management (VBM) - value oriented management or management based on the evaluation of value or as management of company value. However, the VBM concept did not give organizations any competitive advantage, as could be expected to come from the transformation of the economic aspects of their operation. Therefore, it appeared necessary to develop an instrument of management, which would help to develop the market potential of the organization, while at the same time giving account to the social aspects of its operation. The Management by Values (MBV) concept is one of such instruments. MBV is sometimes defined as neo-humanism. The system assumes cultural reconstruction, which relates to the humanistic theories of organizational development. MBV 
helps to incorporate the ethical and ecological resources into the process of the organization's strategic management. Management by values represents both the business ethics (related to organizational beliefs and values) and possibilities of competitive diversification (Dolan, Garcia 2009 p. 24).

Management by values is a process in which elements of the organization's environment and its internal structure are impacted upon. It is a process which is implemented in accordance with the organization's core values. Management by values comprises activities which are directed at the growth of the organization's value, which comes from the increased level of employees' identification with the values and the formation of internally consistent system of values. Day to day activities of the employees consistent with the organizational values help them identify with the company. Complete identification means that they not only observe the principles and procedures of organizational conduct but also accept the value system dominant in the organization.

\section{The model form of the Management by Values concept}

Management by values can be treated as a management method of three categories (or dimensions) of organizational values, which impact on the behaviour of the organization members:

1. Pragmatic values,

2. Ethical and social values,

3. Emotional values.

Pragmatic values are connected with the economic aspects of company operations. They are necessary to support and integrate a variety of organizational subsystems. They relate to performance, product standards and work productivity. These values have an impact on such activities as planning, ensuring quality and accounting.

Ethical and social values are common to all employees and determine how people behave in groups. They are related to such social values as honesty, respect and loyalty. Ethical and social values impact on the behaviour of organization members in the process of forming pragmatic values. Emotional values are connected with individual feelings of organization members related to trust, self-awareness, self-confidence, openness and flexibility.

Management by values can be presented as a three-dimensional model, based on the "organizational core" (key organizational values) and the formation of the organizational culture, consistent with the company's values and its strategic objectives (fig. 1). 


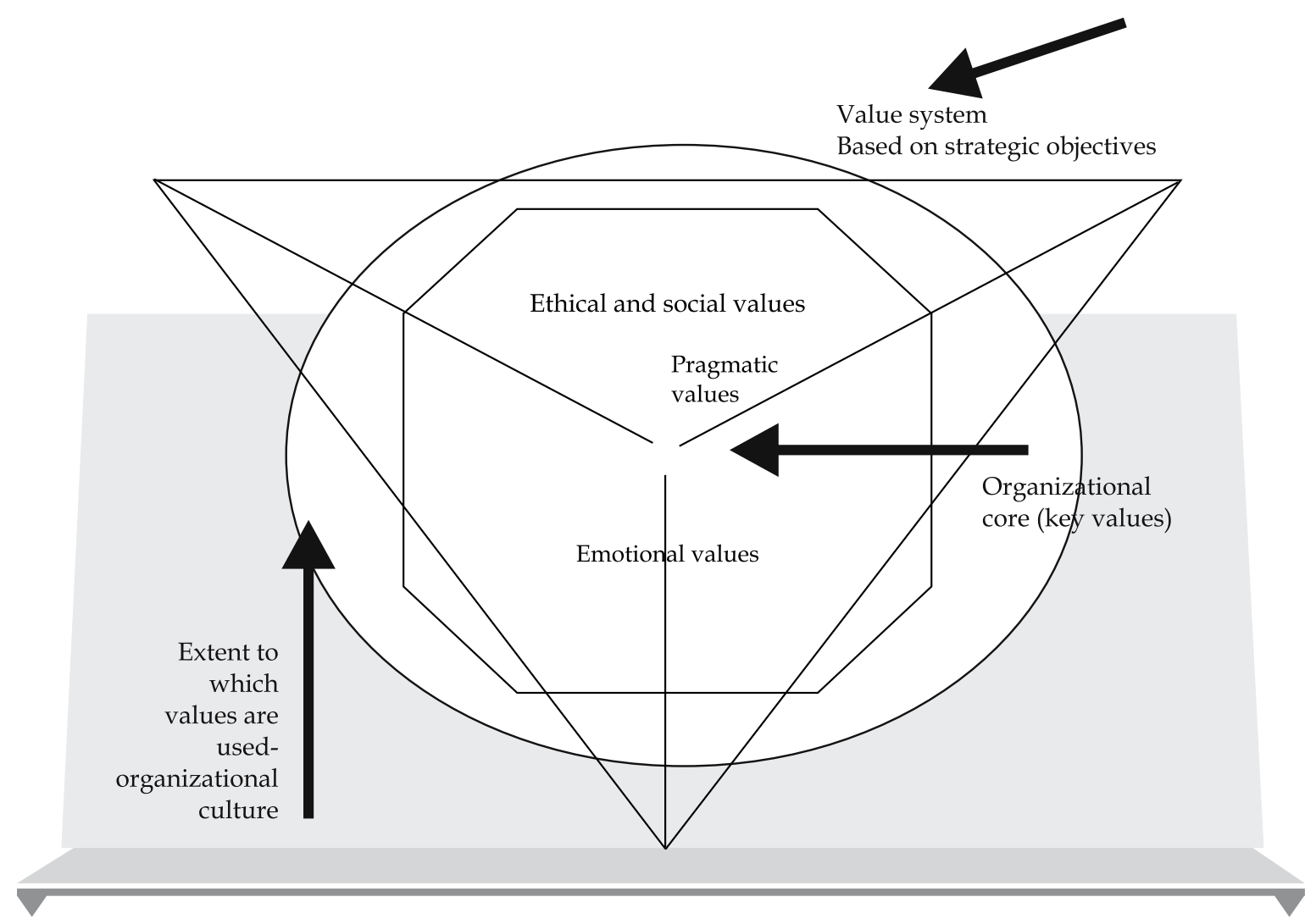

Fig. 1. Three-dimensional MBV model Dolan, Garcia 2009 p. 48

Source: own compilation

Management by values is also a method to integrate the process of strategic management with the human resources management system and the formation of organizational loyalty process (Rokeach 1983).

According to the MBV concept there are three factors which motivate members of the organization to achieve high results: knowledge, empowerment and involvement. Employees' beliefs consistent with the values represented by company management determine their motivation to work effectively, be attached to the organization, aspire for self-improvement and be creative in the improvement of organizational processes. The relation between the beliefs of the individual and organizational values is necessary for members of the organization to understand the meaning of their work (fig. 2). 


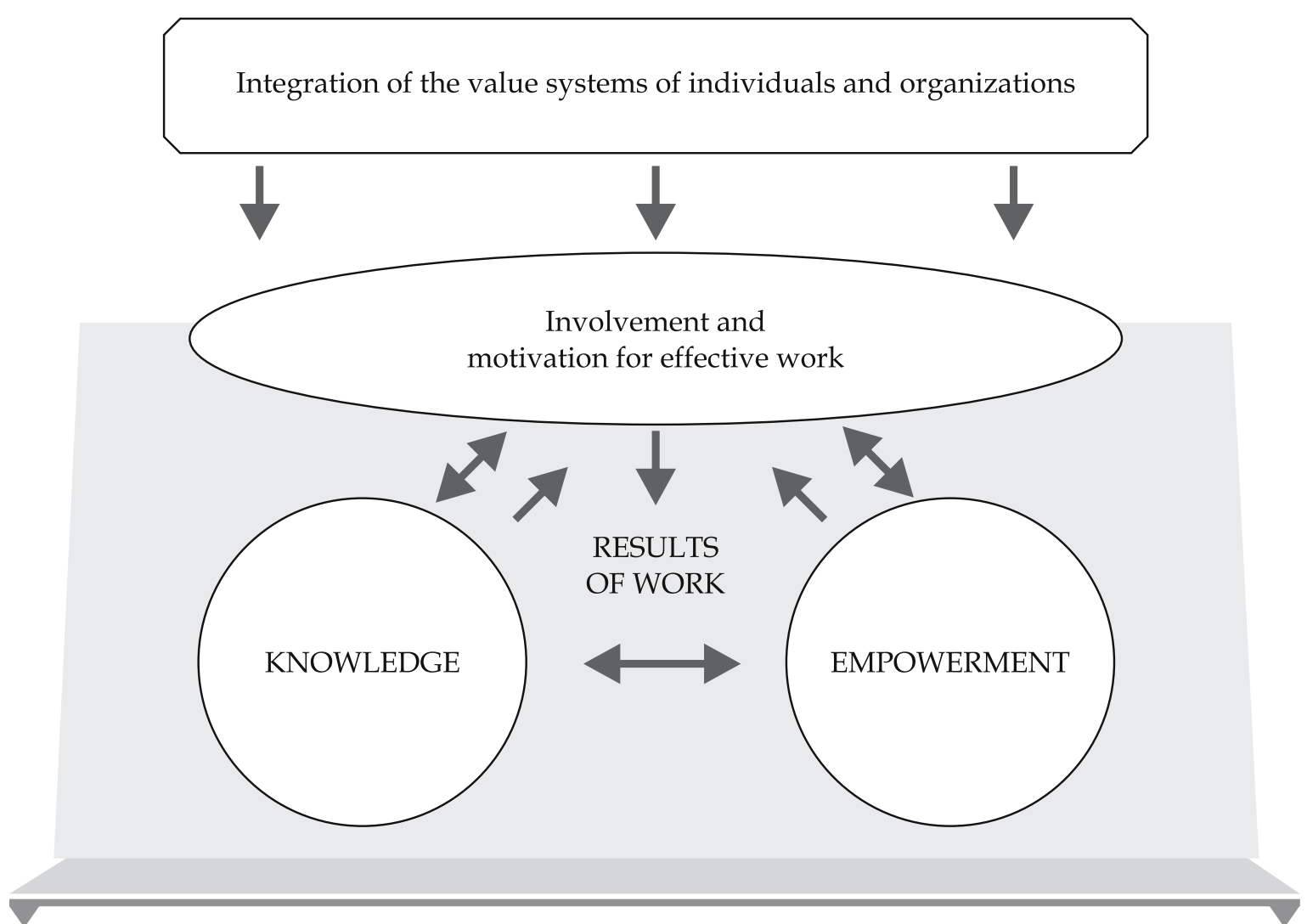

Fig. 2. Three factors, which influence work effectiveness: knowledge, involvement and empowerment

Source: own compilation

\section{Management by Values vs. organization's strategy}

The management by values process is a sequence of uninterrupted, ordered activities related to the formation, support and strengthening of a single system of the organization's values in order to increase its goodwill. The management by values process must answer the following questions:

- what is the present structure of the organization's value system?

- in which directions should transformations of the value system be made so that it helps to implement the organization's strategy?

- what contradictions can exist in the value system?

- what action should be taken to increase the internal consistency of the value system?

Management by values should be closely related to the strategies implemented 
and pursued in the company. An adequate strategy of management by values is required to choose a specific strategy of a company. It must be oriented to the set of values and must be characterized by adequate characteristics related to values.

Strategy implementation is connected with strategic changes of organizational culture with values being its central element. One can say that implementation of this strategy is determined by a relevant selection of the management by values strategy. Depending on the type of strategy chosen by the organization, the system of values should be modified accordingly (table 1).

\section{Table 1. Possible relations between the strategy and the organization's value system}

\begin{tabular}{|c|c|c|c|c|}
\hline Strategy type & $\begin{array}{l}\text { Key val- } \\
\text { ues - ob- } \\
\text { jectives }\end{array}$ & Values - means & $\begin{array}{l}\text { Recommended } \\
\text { type of man- } \\
\text { agement by } \\
\text { values strategy }\end{array}$ & $\begin{array}{l}\text { Basic indica- } \\
\text { tor of man- } \\
\text { agement by } \\
\text { values }\end{array}$ \\
\hline $\begin{array}{l}\text { 1. Concentrated growth } \\
\text { strategies } \\
\text { - market position } \\
\text { strengthening strategy } \\
\text { - market development strategy } \\
\text { - product development } \\
\text { strategy }\end{array}$ & Growth & $\begin{array}{l}\text { Quality } \\
\text { Effectiveness } \\
\text { Consistent action }\end{array}$ & $\begin{array}{l}\text { Strengthening } \\
\text { strategy }\end{array}$ & $\begin{array}{l}\text { Value system } \\
\text { stability index }\end{array}$ \\
\hline $\begin{array}{l}\text { 2. Integrated growth strategies } \\
\text { - horizontal integration } \\
\text { strategy } \\
\text { - vertical integration strategy }\end{array}$ & $\begin{array}{l}\text { Expan- } \\
\text { sion }\end{array}$ & $\begin{array}{l}\text { Partnership } \\
\text { Mutual obligations } \\
\text { Equilibrium }\end{array}$ & $\begin{array}{l}\text { Value system } \\
\text { integration } \\
\text { strategy }\end{array}$ & $\begin{array}{l}\text { Value } \\
\text { homogeneity } \\
\text { level }\end{array}$ \\
\hline $\begin{array}{l}\text { 3. Diversified growth strategies } \\
\text { - concentric diversification } \\
\text { - conglomerate diversification }\end{array}$ & $\begin{array}{l}\text { Develop- } \\
\text { ment }\end{array}$ & $\begin{array}{l}\text { Innovation } \\
\text { Risk acceptance } \\
\text { Pro-activity } \\
\end{array}$ & $\begin{array}{l}\text { Launch } \\
\text { strategy }\end{array}$ & $\begin{array}{l}\text { Cultural } \\
\text { accumulation } \\
\text { level }\end{array}$ \\
\hline $\begin{array}{l}\text { 4. Reduction strategy } \\
\text { - stabilization and support } \\
\text { - reduction of expenditure } \\
\text { - strategic return } \\
\text { (breakthrough) } \\
\text { - divestments } \\
\text { - separation } \\
\text { - liquidation }\end{array}$ & $\begin{array}{l}\text { Stabiliza- } \\
\text { tion }\end{array}$ & $\begin{array}{l}\text { Security } \\
\text { Discipline } \\
\text { Professionalism }\end{array}$ & $\begin{array}{l}\text { Support } \\
\text { strategy }\end{array}$ & $\begin{array}{l}\text { Cultural } \\
\text { separateness }\end{array}$ \\
\hline
\end{tabular}

Depending on the selected strategic direction, the basic values (objectives) are growth, development, harmony or stabilization (Harpeslagh 2001)

Source: own compilation

11

KAZIMIERZ KRZAKIEWICZ 
Growth as a linear, unidirectional change is necessary to implement the concentrated growth strategy, market- and product-oriented. Expansion, on the other hand, is necessary for the implementation of the integrated growth strategies, oriented towards the increase of the company size following mergers and acquisitions. Development as change in different directions and at different pace is characteristic of the diversified growth strategy. Harmony - a value, which ensures that cultural differences are broken as a result of strategic changes, is a core value for the stabilization strategy. Stabilization is oriented to support the values dominant in the environment, during the implementation of the strategies of liquidation, divestment or strategic return. All value related strategies have specific means to achieve the objectives (indirect values).

Management by values should be based on the result of the audit of those values, which are dominant in the organization, and the audit of the strategic directions of the company development. In order to implement the strategic objectives of a company it is necessary to evaluate the consistency of its present organizational culture (its key values) and proposed strategic values. Lack of consistency should be eliminated through the use of the relevant management by values strategy oriented to strengthen the existing value system (strengthening strategy), incorporation of new values into the organizational culture (launch strategy), elimination of "redundant" values from the system (exclusion strategy).

Implementation of any strategy depends on the quality of human capital. According to D. Norton and R. Kaplan's (2001) concept strategic professions, which endure and accelerate the implementation of the strategic objectives, should be identified in any strategic process. Groups of strategic professions include organizational positions or functions at which members of the organization, who have the right competencies and skills, should ensure implementation of strategic tasks. A description of relevant requirements should be described in the competency profile.

At the first stage a company defines the groups of professions, which are decisive to the success of the strategy. At the second stage requirements specific of professions should be defined, i.e. a competency profile must be prepared. It should include a description of knowledge, skills and habits as well as values necessary for effective work at a given position.

A comparison between the actual characteristics of the organization members and the requirements of the competency profile can be treated as a "competence gap", which reflects the degree of readiness of the company's human capital to implement the strategy.

The concept of strategic readiness introduced by Kaplan and Norton is an 
analogy to the liquidity ratio - the higher the degree of readiness, the faster the intangible assets can be transformed into financial results. Strategic readiness transforms into a tangible value.

Members of the organization, who have achieved the highest degree of readiness, are the main factor contributing to the creation of shareholder value. Within the framework of management by values the concept of strategic readiness should be understood as the level of consistency between the value system of a given employee with the values of the strategic positions defined by the elements of the profile and/or a set of reasons for their transformations. If transformation of the value system is necessary, a programme of human capital strategic development is prepared, i.e. tactical programmes of transformation of organizational values. These programmes define the directions in which the value system will be transformed. The transformations are necessary to increase the internal consistency of the value system of each employee who holds a specific strategic position.

\section{Conclusion}

The present stage of economic development requires definition of a value system as a system of coordinates within which modern organizations will be developing. In this context management by values is a process of identification, formation and consolidation of values, which, on the one hand should contribute to strategic development and on the other ensure consistency of human resources necessary for the development of the selected strategy.

The ability of managers to identify and use a value system in management, which help them create competitive advantages of their companies, are fundamental to the process of cooperation based on common interests. An audit of values is of particular importance here. Determination of the consistency level within the value system is a departure point for the selection of the management by values technique.

In the management by values process managers must:

- identify values of strategic importance for the organization,

- support values consistent with the organization's strategy through the appropriate management by values policy,

- transform the value system of organization's members in the right way.

Values of the organization are formed in the process of appropriate actions taken by the managers, including:

- determination of strategic values of an organization, 
- promotion of the appropriate value system,

- support of the organization members who accept the selected value system,

- stimulation of organizational behaviours which are consistent with the proposed value system.

Good understanding of the organization's strategic objectives helps its management to define priority values and formulate them in such a way that they motivate the organization's members to act actively. Values, which are the core of the organizational culture, are the key link deciding about the consistent action of the organization members in different units and organizational cells, at all hierarchy levels, about the unity of views and action, and, ultimately, the effective implementation of the organization's objectives. When an employee identifies with organization s/he not only respects the formal principles of its operation but also accepts the organizational system of values.

\section{Summary}

\section{Management by Values - a strategic dimension}

This article presents the strategic aspects of the Management by Values concept. The author tries to prove that implementation of this concept in an organization helps to form a stable and competitive organizational culture, which is accepted by the organization's members. MBV can be defined as a philosophy and practice of management, linking the basic values of the organization with its strategic objectives.

It has been assumed that leadership has always been connected with human values. The role of the leader is to manage the organization consistently with its strategic objectives and basic values. This requires that a system of values be created, which members of the organization will adhere to in their work. By making the strategic vision "more human", the organization can not only survive but also ensure growth with the optimal financial result, using the personal involvement of its internal and external stakeholders.

Keywords: pragmatic values, ethical and social values, emotional values, organization's strategy, Management by values.

\section{Streszczenie}

Management by Values - wymiar strategiczny

Celem artykułu jest przedstawienie strategicznych aspektów 
Słowa

koncepcji Management by Values. Autor stara się wykazać, iż wykorzystanie w przedsiębiorstwie tej koncepcji umożliwia kształtowanie stabilnej, konkurencyjnej i akceptowanej przez członków organizacji kultury organizacyjnej. MBV można określić jako filozofię i praktykę zarządzania, łączące podstawowe wartości organizacji z jej strategicznymi celami.

Przyjmuje się tutaj, że przywództwo w swej istocie, zawsze było związane z wartościami człowieka. Zadaniem przywódcy jest w tym ujęciu kierowanie organizacją zgodnie $\mathrm{z}$ jej strategicznym celem i podstawowymi wartościami. Wymaga to stworzenia systemu wartości, którymi kierują się w swoich działaniach członkowie organizacji. "Humanizując” wizję strategicznac organizacja może nie tylko przetrwać, lecz także zapewnić sobie wzrost przy optymalnym wyniku finansowym, wykorzystując osobiste zaangażowanie wewnętrznych i zewnętrznych interesariuszy.

kluczowe: wartości pragmatyczne, wartości etyczno-społeczne, wartości emocjonalne, strategia organizacji, zarządzanie przez wartości.

\section{References}

1. Amstrong M. (2005), Zarządzanie zasobami ludzkimi, Oficyna Ekonomiczna, Kraków.

2. Dolan S. L., Garcia S. (2009) Managing by Values, Macmillan, New York.

3. Harpeslagh P., Noda T., Boulos F. (2001), Managing for Value, Harvard Business Review, No 79. p. 65-73.

4. Kaplan R., Norton D. (2001), Zrównoważona karta wyników, Warszawa.

5. Rokeach M. (1983), The nature of human values, The Free Press, New York.

6. Van Assen M., Van Der Berg G., Pietersma P. (2009), Key management models, Prentice - Hall, Englewood Cliffs. 